\title{
KORUPSI DAN KETIDAKSETARAAN GENDER SEBAGAI TANTANGAN UTAMA GOOD GOVERNANCE DI INDIA
}

\author{
Winny Permataningtyas \\ Pascasarjana Hubungan Internasional, Fakultas Ilmu Sosial dan Politik \\ Universitas Indonesia \\ winnypermata.2206@gmail.com
}

\begin{abstract}
Abstrak
India merupakan negara di wilayah Asia dengan jumlah penduduk kedua terbanyak di dunia setelah Tiongkok. Pertumbuhan ekonominya yang mencapai 6 hingga 7 persen selama 10 tahun terakhir ini membuat India menjadi salah satu negara berkembang dengan perekonomian yang berkembang sangat pesat. Namun sayangnya, di balik pertumbuhan ekonomi yang pesat itu, India memiliki isu lama yang terus menghantui di belakangnya yakni isu kesetaraan gender dan korupsi. Kedua isu tersebut terus membayangi perpolitikan di India dan menjadi alasan utama marak terjadinya isu-isu sosial lainnya seperti kemiskinan, pengangguran, lemahnya sistem pemerintahan, hingga hilangnya hak-hak perempuan di salah satu negara demokrasi terbesar di dunia ini. Tulisan ini akan menguraikan indikatorindikator ketidaksetaraan gender dan korupsi yang berujung pada terhambatnya pencapaian good governance di India. Pentingnya kehadiran kesetaraan gender dan ketegasan dalam pemberantasan kasus korupsi akan dijelaskan dalam tulisan ini sebagai bentuk saran untuk mencapai good governance di dalam negara khususnya di India.
\end{abstract}

Kata Kunci : India, kesetaraan gender, korupsi, good governance

\section{Abstract}

India is a country in the Asian region with the second largest population in the world after China. Its economic growth, which has reached 6 to 7 percent over the last 10 years, has made India one of the developing countries with a very fastgrowing economy. But unfortunately, behind this rapid economic growth, India has an old issue that continues to haunt behind it, namely the issue of gender equality and corruption. These two issues continue to overshadow Indian politics and are the main reason for the rise of other social issues such as poverty, unemployment, weak government systems, and loss of women's rights in one of the largest democracies in the world. This paper will describe the indicators of gender inequality and corruption which have resulted in obstruction of the achievement of good governance in India. The importance of gender equality and assertiveness in eradicating corruption cases will be explained in this paper as a form of advice for achieving good governance in the country, especially in India.

Keywords: India, gender equality, corruption, good governance. 


\section{PENDAHULUAN}

Isu kesetaraan gender dan korupsi merupakan isu yang kerap kali terjadi di berbagai negara di dunia. Tingginya intensitas kejadian kedua isu tersebut telah membuat banyak pihak baik dari kalangan individu maupun pemerintah yang menganggapnya lumrah untuk terjadi sehingga tidak menjadi isu yang darurat untuk diatasi. Padahal, dampak buruk yang disebabkan baik oleh tidak adanya kesetaraan gender atau tingginya kasus korupsi dapat dirasakan langsung oleh masyarakat biasa dan tak jarang menjadi penghambat negara yang bersangkutan untuk terus maju dan berkembang. Kedua isu tersebut seakan menjadi batu besar yang menghalangi dan tak jarang sulit untuk dilewati.

Kebanyakan negara yang masih berkutat baik dengan isu kesetaraan gender maupun isu korupsi adalah negara-negara berkembang dengan tingkat pendapatan per kapita yang masih tergolong relatif rendah. Tata kelola di negara-negara tersebut yang sering kali belum baik memperkeruh kemampuan untuk menyelesaikan kedua isu tersebut. Pemerintah di negara berkembang acap kali dianggap sebagai pemerintahan yang lemah karena sistem hukum yang tidak tegas ditegakkan, kurangnya transparansi dalam sistem, diskriminasi kelompok yang kerap terjadi, serta minimnya tingkat partisipasi politik. Berbagai negara di berbagai belahan dunia hingga hari ini masih tersandung kedua isu tersebut. Beberapa contoh negara yang masih menderita dan terjerat di dalam isu kesetaraan gender dan korupsi adalah Nigeria, Nikaragua, Zimbabwe, Kenya, dan juga India.

Isu kesetaraan gender dan tingginya angka korupsi bukanlah sesuatu yang asing jika kita membahas tentang India. Kedua permasalahan ini telah terjadi sejak zaman nenek moyang di India dan terus turun menurun meski zaman telah berganti, globalisasi telah hadir, dan bahkan dunia sudah menjadi lebih modern dibandingkan zaman dahulu kala. Ketidaksetaraan gender dan juga tingginya angka korupsi di India seakan sudah mendarah daging dalam sistem pemerintahannya. Hal ini memang tidak bisa dilepaskan dari kuatnya norma, budaya, serta nilai yang dipercayai oleh masyarakat India. 
Berdasarkan nilai, norma dan kepercayaan yang dianut oleh masyarakat India, laki-laki memiliki posisi yang lebih tinggi dibandingkan perempuan. Tak hanya di dalam rumah tangga, dalam pemerintahan, lingkup kerja, dan berbagai hal lainnya, laki-laki menempati posisi nomor satu sedangkan perempuan selalu berada di posisi ke dua. Nilai-nilai yang sudah tertanam sejak dahulu kala membuat kehadiran kesetaraan gender di India seakan menjadi utopia. Demikian pula keadaan pemerintahan yang bebas dari korupsi, menjadi sebuah utopia karena korupsi kerap terjadi tak hanya di sektor pemerintahan, tetapi juga sektor swasta, bisnis, dan sektor utama lainnya. Rendahnya transparansi yang disebabkan oleh hanya elit-elit politik yang memegang informasi, menyebabkan korupsi menjadi sesuatu yang tidak lagi mencengangkan untuk terjadi.

Atas dasar tingginya angka korupsi dan rendahnya tingkat kesetaraan gender sebagaimana telah digambarkan di paragraf-paragraf sebelumnya, penulis sampai pada suatu rumusan masalah yakni "bagaimana isu korupsi dan kesetaraan gender dapat menjadi tantangan untuk India dalam menciptakan good governance?". Tulisan ini akan memberikan penjelasan serta saran tidak hanya untuk India, tetapi juga bagi negara-negara berkembang lainnya yang terjerat kedua isu kesetaraan gender dan korupsi. Penulis percaya bahwa isu kesetaraan gender dan korupsi memiliki keterkaitan erat satu sama lain yang menjadi penghambat utama bagi sebuah negara menciptakan suatu pembangunan berkelanjutan yang berujung pada sulit terciptanya good governance di negara yang bersangkutan.

Dalam tulisan ini, penulis menggunakan dua indikator penting sebagai variabel utama atas tantangan yang dihadapi oleh negara India untuk mencapai suatu good governance. Dalam melihat indikator sebuah korupsi, penulis akan menggunakan teori realis yang menyatakan bahwa korupsi memiliki kaitan yang sangat erat dengan kepentingan atau keuntungan baik pribadi maupun suatu kelompok tertentu. Sedangkan untuk melihat indikator isu kesetaraan gender, penulis akan menggunakan teori feminisme mengingat kasus kesetaraan gender di India erat kaitannya dengan diskriminasi terhadap perempuan. Tata kelola atau governance yang dimaksud dalam penelitian ini adalah suatu proses dalam pembuatan kebijakan dan proses bagaimana kebijakan tersebut diimplementasikan. 
Konteks dari konsep tata kelola sangat beragam seperti tata kelola sebuah perusahaan, tata kelola dunia internasional, juga tata kelola nasional suatu negara. Dalam penelitian ini, tata kelola yang dimaksud adalah tata kelola nasional suatu negara (India). Sebuah tata kelola dapat dikatakan baik (good governance) apabila memenuhi 6 karakteristik utama yakni: a) partisipasi; b) orientasi konsensus; c) akuntabilitas; d) transparansi; e) adil dan inklusif; dan f) mematuhi peraturan dalam hukum.

Seperti telah dijabarkan sebelumnya, isu korupsi dan kesetaraan gender merupakan isu kuno yang masih terjadi hingga zaman sekarang di India. Jeevan S.Rajak (2013) dalam tulisannya berjudul "Corruption in India: Nature, Causes, Consequences and Cure", menyatakan bahwa korupsi merupakan suatu masalah yang sudah sangat mengerak di India. Joshi (2005) mengategorikan korupsi di India ke dalam 4 kategori yakni korupsi politik, korupsi dalam program kerja, korupsi dalam proyek, dan juga suap. Di sisi lain fenomena diskriminasi terhadap perempuan juga sudah terjadi sejak tahun 1980. Di berbagai belahan di India, perempuan sering kali dianggap sebagai beban ekonomi dan finansial meskipun sudah berkontribusi bagi keluarga mereka sendiri. Isu ketidaksetaraan gender ini merupakan akar dari isu-isu lain seperti hak atas properti, sulitnya akses terhadap kredit bagi perempuan, juga rendahnya partisipasi wanita dalam angkatan kerja.

Dalam sistem parlemen India, tanggung jawab untuk melakukan eksekusi terkait kebijakan-kebijakan yang telah dibuat oleh pemerintahan legislatif diambil alih oleh birokrasi itu tersendiri. Sedangkan, birokrasi di India pun tidak dapat dipercaya karena termasuk dalam kategori zona merah kasus korupsi serta memiliki prosedur yang sangat rumit. Tata kelola di India juga dikategorikan sebagai tata kelola yang tidak transparan dalam penegakan peraturannya. Hal-hal tersebut yang menyebabkan korupsi di India sudah terjadi bahkan sejak negara India merdeka (Ganguly, 2012 \& Kundu, 2015). Kedua penulis tersebut juga menyebutkan bahwa korupsi di India merupakan korupsi di India merupakan warisan yang turun menurun dalam pemerintahan India. Pada pemilihan umum (pemilu) pertama di India pada tahun 1951, Sebagian dari anggota kongres dijatuhi tuduhan atas tindakan korupsi. Jaringan korupsi di India sudah menjadi makanan sehari-hari 
masyarakat di sana sehingga tidak lagi dianggap sebagai sesuatu yang asing (Miklian, 2013). Jaringan korupsi di India dapat didefinisikan sebagai sebuah interaksi finansial dan birokrasi yang dilakukan oleh masyarakat serta perusahaanperusahaan dengan perwakilan pemerintah dari semua tingkatan. Dengan demikian, tidak heran jika Tindakan korupsi di India erat kaitannya dengan black market di berbagai sektor industri (Miklian\&Carney, 2013). Permasalahan korupsi merupakan akar dari berbagai masalah sosial lainnya seperti isu keadilan, akses terhadap power, transparansi informasi, serta tidak harmonisnya hubungan antara negara dengan masyarakat.

Dalam tatanan negaranya, isu kesetaraan gender juga menjadi sorotan utama dalam lingkungan sosial di India. Banyak tulisan-tulisan yang menjabarkan bahwa India memiliki tingkat yang sangat rendah dalam perihal kesetaraan gender. Singh (2016) dalam tulisannya yang berjudul "The state of Gender Inequality in India" menyatakan bahwa tidak hanya akses terhadap sumber daya dan kesempatankesempatan yang dibatasi bagi perempuan, namun hal-hal yang berkaitan dengan prospek kehidupan bagi perempuan tersebut sangat dibatasi di India. Perempuan di India hanya dapat melakukan pekerjaan domestik. Akses partisipasi perempuan di sektor ekonomi, politik, sosial, bahkan pendidikan sangat dibatasi. Padahal, rendahnya tingkat pendidikan pada wanita dapat menjadi akar bagi permasalahan sosial lainnya seperti rendahnya edukasi seks, pernikahan dini, bahkan dapat meningkatkan risiko terjangkitnya penyakit HIV/AIDS pada perempuan (The National Family Health Survey, 1998-1999). Rendahnya tingkat pendidikan bagi perempuan di India juga menyebabkan minimnya partisipasi perempuan terhadap politik di India. Padahal, dalam sistem demokrasi yang utuh, adanya kesetaraan gender merupakan salah satu prasyarat dasar. Partisipasi perempuan dalam politik bukan sekedar untuk memberikan hak pilih pada masyarakat dengan gender perempuan, namun sebagai bentuk sharing power dan keterlibatan perempuan dalam setiap pembuatan kebijakan dalam tata kelola pemerintahan di suatu negara (Krishnaveni, 2017).

Sebagaimana penulis nyatakan sebelumnya, kedua isu korupsi dan kesetaraan gender memiliki kaitan satu sama lain dalam menciptakan suatu tata 
kelola yang baik (good governance) dalam sebuah pemerintahan. Department of International Development, Britania Raya (2015) menjelaskan bahwa perempuan cenderung tidak akan melakukan Tindakan korupsi dibandingkan dengan laki-laki. Penelitian dari Bank Dunia (World Bank) juga menemukan bahwa semakin tinggi perwakilan wanita dalam suatu pemerintahan berbanding lurus dengan semakin rendahnya tingkat korupsi di pemerintahan tersebut. Dalam kasus India, mengingat rendahnya angka partisipasi perempuan di ranah pendidikan yang menyebabkan rendahnya partisipasi wanita di politik, juga menunjukkan bahwa kebanyakan korupsi dilakukan oleh laki-laki.

Kedua indikator korupsi dan juga kesetaraan gender akan dibahas lebih lanjut untuk melihat kaitannya dengan terciptanya suatu good governance. Penelitian ini menggunakan metode kualitatif melalui extensive study literature yang bersumber dari publikasi sebelumnya berkaitan dengan gender, korupsi, juga good governance.

\section{PEMBAHASAN}

\section{A. Korupsi di India}

Korupsi merupakan sebuah terminologi yang memiliki banyak definisi dari berbagai ahli. Kata "corrupt" pertama kali digunakan oleh Aristoteles dan kemudian digunakan pula oleh Cicero untuk mendefinisikan sebuah perihal perampokan dan penolakan atas perilaku yang baik. Menurut kamus Oxford, kata "corrupt" berarti "dipengaruhi oleh perampok, khususnya pada saat pemilu". Ensiklopedia Britannica juga mengatakan bahwa korupsi merupakan suatu praktik yang melibatkan perampokan; namun memiliki hubungan dengan sistem pemilihan. Sedangkan menurut KBBI, korupsi berarti penyelewengan atau penyalahgunaan uang negara (perusahaan dan sebagainya) untuk keuntungan pribadi atau orang lain.

Morris menuliskan bahwasanya korupsi merupakan suatu penggunaan kekuatan publik yang ilegal dan hal tersebut bertujuan untuk mendapatkan keuntungan untuk kepentingan pribadi atau suatu kelompok tertentu. Hal tersebut sama dengan definisi yang diberikan oleh World Bank yakni korupsi merupakan 
"abuse of public power for private benefit" namun, keuntungan pribadi yang dimaksudkan disini tidak hanya untuk kepentingan pribadi atau hanya satu orang melainkan juga dapat menguntungkan suatu kelompok tertentu baik dalam suatu perusahaan maupun dalam pemerintahan.

India menempati peringkat 80 dari 180 negara di tahun 2019 berdasarkan dari Corruption Perception Index (CPI). Dilihat dari tahun 2012 hingga tahun 2019, total nilai yang didapatkan oleh India terkait dengan penilaian indeks korupsi di India tidak terlalu meningkat secara signifikan. Itu berarti, kasus-kasus korupsi masih kerap terjadi di negara India dari tahun ke tahunnya.

Tabel 1. 1 Nilai Persepsi Indeks Korupsi di India Tahun 2012-2019

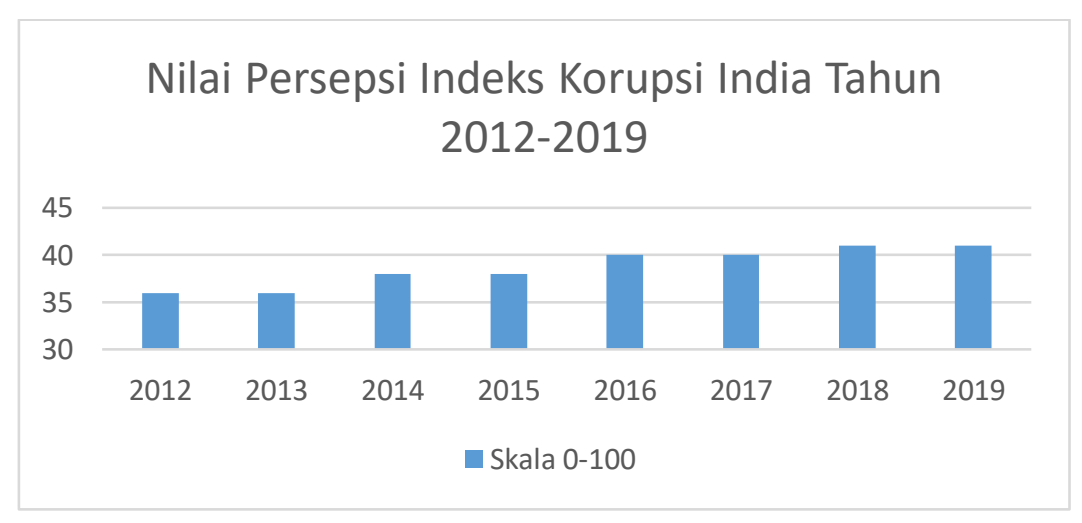

Sumber: Transparency International

Berdasarkan tabel di atas, dapat dilihat bahwa nilai persepsi indeks korupsi di India dari tahun ke tahun sejak 2012 hingga 2019 mengalami peningkatan. Berdasarkan Transparency International, hal ini menunjukkan suatu kemajuan dalam pemberantasan korupsi mengingat semakin tinggi persepsi indeks korupsi, semakin rendah pula tingkat korupsi di negara tersebut. Hanya saja dalam kasus India, sejak tahun 2012 hingga 2019 hanya meningkat sebanyak 5 poin yang artinya kemajuan dalam pemberantasan kasus korupsinya sangat rendah. Nilai 41 yang didapat India pada tahun 2019 masih menunjukkan bahwa negara India memiliki kecenderungan untuk korupsi yang cukup tinggi dan India tergolong dalam zona kuning.

Kasus-kasus korupsi yang dilakukan oleh para politisi di India dan pihakpihak lainnya dalam sistem birokrasi adalah sebagai berikut:

1. Coalgate Scam (Cost - 186000 Crores) 


\section{2 G Spectrum Scam (Cost -176000 Crores)}

\section{Commonwealth Games Scam (Cost - 70000 Crores)}

Sebagaimana telah disebutkan sebelumnya, korupsi di India sudah mendarah daging dalam sistem pemerintahan dan birokrasinya. Kasus korupsi yang telah menjalar di hampir seluruh lapisan pemerintahan di India sudah berawal sejak India merdeka. Konstitusi pemerintahan di India terdiri dari tiga bagian yakni legislatif, eksekutif, dan yudikatif. Fungsi dari tiap-tiap bagian sama seperti pemerintahan demokrasi lainnya. Namun sayangnya, perilaku untuk melakukan korupsi telah menjadi tingkah laku dasar para pihak yang menduduki kursi pemerintahan.

Terdapat beberapa penyebab menjalarnya korupsi di berbagai sektor di India yakni (Arman, 2011 \& Kundu, 2015):

a. Kurangnya efektivitas dalam manajemen dan organisasi. Kurangnya pengontrolan dan pemantauan pada proses administrasi mengantarkan kepada tindakan korupsi. Selain itu, penunjukan pihak manajer maupun badan eksekutif lainnya yang tidak efisien dan tidak kapabel juga mengantarkan pada perihal mis-manajemen. Oleh karena itu, akibat dari adanya kesalahan penunjukan adalah korupsi dan hal tersebut akan terus menerus dilakukan.;

b. Kurangnya stabilitas ekonomi. Krisis perekonomian dan adanya kenaikan harga yang cukup signifikan mengakibatkan adanya perubahan dalam gaya hidup masyarakat. Kebanyakan masyarakat dalam menghadapi situasi tersebut untuk melanjutkan hidup akan melakukan hal-hal yang ilegal dan jauh dari nilai-nilai moral. Mereka lebih memilih menggunakan "jalan pintas" untuk mencapai keinginannya daripada harus bekerja keras. Hal tersebut akan menjadi suatu kebiasaan sehingga kebanyakan pemangku kebijakan yang menggunakan "jalan pintas" cenderung akan melakukan tindak korupsi.;

c. Pemilihan umum. Pada saat pemilihan umum, korupsi berada di puncaknya karena pada saat itu terjadi pihak-pihak yang memiliki kepentingan-kepentingan personal (industrialis terkemuka) memberikan biaya kepada para politisi untuk melakukan kampanye selama periode sebelum pemilihan umum. Para pemilik kepentingan personal melakukan penyuapan agar dapat memengaruhi politisi di kemudian hari, dan dengan penyuapan tersebut politisi bisa mendapatkan suara sehingga memenangkan pemilihan. Biasanya politisi akan melakukan penyuapan kepada masyarakat yang perekonomiannya kurang dan kurang berpendidikan.; 
d. Kurangnya kesadaran dan kerelaan masyarakat. Apabila masyarakat memutuskan untuk tidak setuju atau tidak melakukan penyuapan di setiap proses administrasi maupun institusi politik maka tingkat korupsi akan dapat berkurang. Namun hal tersebut kembali lagi kepada proses administrasi yang cenderung lambat karena adanya mis-manajemen yang mana banyak pihak-pihak yang tidak kapabel mengurusi hal tersebut serta kurangnya pendidikan bagi masyarakat dan adanya krisis perekonomian yang menuntut beberapa pihak melakukan penyuapan dan tindak korupsi.

Tindakan korupsi di India berdampak kepada banyak hal, yaitu: a) Meningkatkan kemiskinan., b) Meningkatkan isu kelaparan., c) Hilangnya kekayaan untuk negara India., d) Rendahnya tingkat kesejahteraan hidup., e) Rendahnya tingkat keadilan hukum. Dampak-dampak yang dihasilkan dari tindak korupsi ini tidak hanya merugikan pihak-pihak maupun sektor tertentu melainkan banyak sekali pihak yang terkena dampak dari tindak korupsi dan tidak hanya di sektor pemerintahan melainkan dalam sektor sosio-ekonomi juga terkena dampak dari masifnya tindak korupsi. Apabila dianalogikan, korupsi ini seperti "spaghetti bowl", yang berarti bahwa antara satu dengan yang lain saling berkaitan sehingga menghasilkan sesuatu yang lebih kompleks lagi dan sulit sekali untuk diuraikan satu persatu.

Sebagian besar tindak korupsi yang dilakukan oleh beberapa pihak secara umum bertujuan untuk mendapatkan keuntungan pribadi (personal gain) atau untuk mencapai kepentingan suatu kelompok. Mengingat sifat dasar dari manusia itu sendiri adalah tidak baik dan ingin menang sendiri, maka mereka melakukan tindak korupsi. Manusia dapat dikatakan sebagai Homo Hominilupus, yakni manusia adalah serigala bagi manusia lainnya, yang kuat akan memakan yang lemah atau yang kuat akan menindas yang lemah. Pihak yang kuat di sini merupakan para pemangku kebijakan atau para birokrat yang melakukan tindak korupsi untuk keuntungannya sendiri dan menindas masyarakat yang lemah agar kepentingannya tetap terjaga.

Sudah jelas sekali bahwa dengan masifnya tindak korupsi menandakan bahwa tata kelola di negara tersebut tidak baik. Menurut tulisan yang diterbitkan oleh United Nations Economic and Social Commission for Asia and the Pacific, 
beberapa karakteristik untuk menciptakan tata kelola yang baik. Kurang lebih terdapat tiga poin yang menyimpang yaitu:

a. Transparansi; Segala bentuk kebijakan yang dibuat harus sesuai dengan peraturan dan regulasi yang ada. Selain itu, perlu adanya informasi secara detail mengenai kebijakan tersebut yang dapat diakses secara bebas oleh seluruh masyarakatnya. Namun, tingginya angka korupsi di India menunjukkan rendahnya angka transparansi dalam setiap kebijakan. Sebagaimana ditunjukkan oleh angka persepsi indeks korupsi di India, angka 41 juga menunjukkan rendahnya transparansi dalam pemerintahan.

b. Peraturan dalam Hukum; Di dalam suatu tata kelola yang baik, kerangka hukum akan bersifat adil. Adanya dukungan dari sektor yudisial dan kepolisian yang bersih sehingga hukum yang berlaku benar-benar dapat ditegakkan dan diterapkan dengan adil. Namun sayangnya, di India, penyuapan kerap terjadi di sektor yudisial dan kepolisian sehingga hukum yang berlaku tidak benar-benar diterapkan sebagaimana mestinya. Angka korupsi yang terus tinggi dari tahun ke tahun menunjukkan lemahnya peraturan dalam hukum India untuk di tegakkan.

c. Efektivitas dan Efisiensi; Menciptakan suatu good governance berarti institusi tersebut akan mengeluarkan kebijakan yang dapat memenuhi kebutuhan masyarakatnya dengan memanfaatkan sumber daya yang ada. Hal ini tidak mencerminkan negara berkorupsi yang mana kebijakan yang diambil bukan untuk memenuhi kebutuhan masyarakat secara luas melainkan untuk memenuhi kebutuhan sebagian orang atau sebagian kelompok yang menguntungkan bagi para birokrasi.

Berdasarkan ketiga indikator di atas, India tidak memenuhi satu pun indikator untuk dapat dikatakan sebagai negara yang memiliki good governance. Dengan demikian dapat terlihat jelas bagaimana korupsi menjadi tantangan dalam terciptanya good governance di India. 


\section{B. Kesetaraan Gender di India}

UNICEF (2017) telah menjabarkan definisi dan konsep terkait dengan kesetaraan gender secara umum yakni suatu konsep yang menempatkan laki-laki dan perempuan memiliki kondisi, perlakuan, dan peluang atau kesempatan yang setara dalam mengembangkan potensialnya secara maksimal dan dalam berkontribusi untuk perkembangan ekonomi, sosial, budaya, serta dunia perpolitikan. Hal tersebut juga sama dengan definisi kesetaraan gender menurut kamus Cambridge yaitu "the act of treating women and men equally".

Menurut KBBI, kesetaraan gender adalah kesamaan kondisi bagi laki-laki dan perempuan untuk memperoleh kesempatan dan hak-haknya sebagai manusia agar mampu berperan dan berpartisipasi dalam kegiatan politik, ekonomi, sosial, budaya, dan kesamaan dalam menikmati hasil pembangunan. Kesetaraan yang dimaksud yakni setara dalam nilai yang diberikan oleh masyarakat. Hal tersebut bukan berarti laki-laki dan perempuan harus menjadi sesuatu yang sama namun lebih kepada hak-hak yang diberikan, tanggung jawab, dan kesempatan harus diberikan tanpa bergantung kepada gendernya laki-laki ataupun perempuan.

Berdasarkan dari laporan Indeks Ketidaksetaraan Gender (GII) yang dipaparkan oleh UNDP di tahun 2018, India menempati urutan ke 122 yang mana 11.7\% bangku pemerintahan ditempati oleh wanita. Hal tersebut jauh lebih rendah daripada Bangladesh yang berada di angka 20.3\%. Dari tahun 2010 hingga 2018 jumlah wanita yang mengenyam pendidikan hingga sekolah menengah atas hanya $39 \%$, jauh berbeda dengan jumlah laki-laki yakni di angka 63.5\%. Begitu pula dengan tingkat partisipasi dalam menjadi tenaga kerja, wanita sebanyak $23.6 \%$ yang mana laki-laki mencapai $78.6 \%$. Angka-angka tersebut jelas memperlihatkan adanya kesenjangan antara wanita dengan laki-laki di berbagai sektor. 
Tabel 1. 2

\section{Perbandingan Jumlah Wanita Pekerja yang Tidak Dibayarkan dengan \\ Laki-Laki}

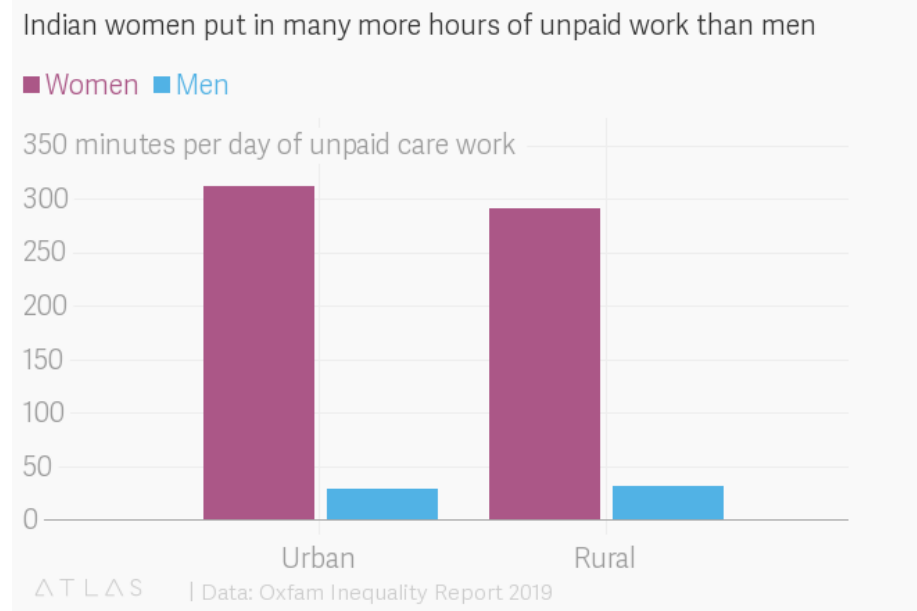

Isu kesetaraan gender di India juga merupakan isu yang telah lama melekat di India. Kasus kesetaraan gender ini pun menyebar di berbagai sektor mulai dari di sektor pendidikan, tempat kerja, hingga partisipasi politik di luar atau di dalam pemerintahan. Contoh yang sering kali terjadi pada wanita di tempat kerja adalah jumlah wanita yang tidak dibayar lebih banyak dibandingkan laki-laki. Tingkat kemampuan literasi wanita dari tahun 2001 hingga 2011 juga tidak terlalu signifikan perkembangannya. Padahal kemampuan literasi merupakan bekal utama seseorang untuk mengenyam pendidikan yang lebih tinggi. Hal tersebut kemudian berdampak kepada rendahnya angka representasi wanita di dalam kursi pemerintahan di India.

Berdasarkan Tabel 1.2, baik di daerah perkotaan maupun pedesaan di India, dari setiap perempuan dengan sekitar 300 menit per harinya yang tidak dibayar, hanya terdapat kurang dari 50 menit dari laki-laki yang tidak dibayar. Kesenjangan ini menunjukkan adanya ketimpangan dalam hal gaji bagi perempuan dan laki-laki yang menyebabkan pendapatan perempuan di India selalu lebih rendah jika dibandingkan dengan pendapatan laki-laki. 
Tabel 1. 3 Perbandingan Tingkat Literasi Wanita dan Laki-Laki di India

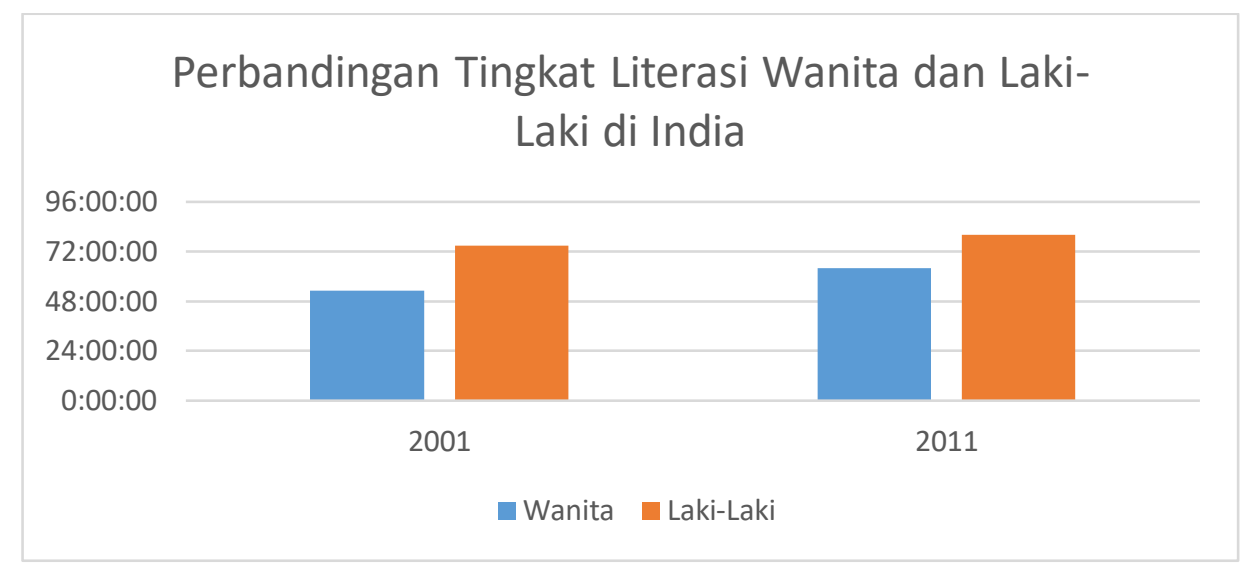

Sumber: MOSPI Government India, 2018

Tabel 1.3 menunjukkan bahwa tingkat literasi laki-laki di India baik pada tahun 2001 maupun 2011 selalu lebih tinggi jika dibandingkan dengan perempuan. Hal ini erat kaitannya dengan rendahnya akses pendidikan bagi perempuan dan juga dibatasinya partisipasi perempuan di sektor pendidikan. Sama seperti isu korupsi, isu kesetaraan gender juga saling berkaitan satu dengan yang lainnya. Adanya gender gap pada tingkat mengenyam pendidikan di India yang masih didominasi oleh laki-laki menyebabkan diskriminasi terhadap perempuan terjadi di tempat kerja dan kurangnya partisipasi politik dari perempuan. Perempuan tidak memiliki pengetahuan maupun edukasi yang lebih tinggi dibanding laki-laki sehingga apabila terjadi diskriminasi seperti di tempat kerja, perempuan tidak dapat melakukan perlawanan karena rendah pengetahuan yang dimiliki. Karena kurangnya pendidikan pun menyebabkan perempuan sulit untuk duduk di bangku pemerintahan dan ikut andil secara langsung dalam pemutusan suatu kebijakan.

Oleh karena itu, kebanyakan kebijakan yang dihasilkan akan menguntungkan laki-laki karena sudut pandangnya hanya dari laki-laki sehingga semakin memperpanjang budaya patriarki yang ada di samping itu semakin masif pula diskriminasi serta gender gap yang terjadi antara laki-laki dengan perempuan (Krishnaveni, 2017). 
Tabel 1. 4

Tingkat Partisipasi Wanita dalam Pemerintahan di India

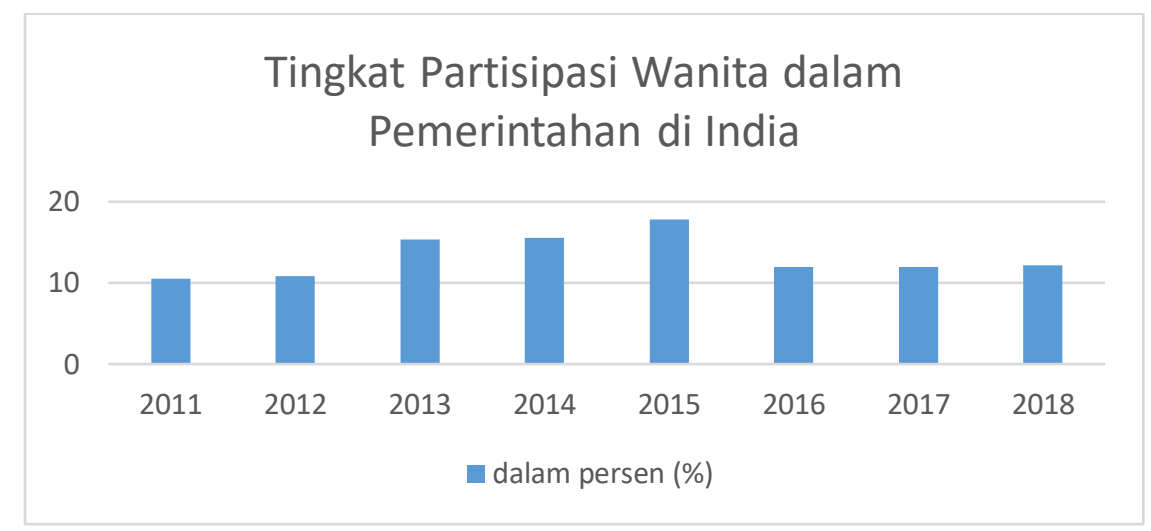

Sumber: MOSPI Government India, 2018

Tabel 1.4 menunjukkan bahwa tingkat partisipasi wanita dalam pemerintahan di India tidak pernah lebih dari 20\%. Artinya, lebih dari $80 \%$ parlemen di India diduduki oleh laki-laki dan memberikan kemungkinan yang tinggi untuk sebuah kebijakan menjadi cenderung menguntungkan gender laki-laki. Padahal sebagai negara demokrasi seharusnya wanita juga memiliki kesempatan yang sama dengan laki-laki mengenai partisipasinya dalam perpolitikan. Dengan adanya partisipasi politik yang aktif dan masif dari wanita di India, akan meningkatkan kualitas demokrasi di India dan dapat memberikan insight baru untuk kebijakan-kebijakan yang akan dibuat nantinya sehingga tidak melulu merugikan pihak wanita di India itu sendiri.

Budaya, kultur, serta nilai yang diyakini oleh sebagian besar masyarakat India juga dapat menjadi salat satu penyebab ketidaksetaraan gender di India tetap bertahan lama hingga zaman modern ini. Konstruksi sosial yang menyatakan bahwa setiap tugas, fungsi, peran, dan nilai-nilai yang berasal dari laki-laki dinilai lebih baik dan menguntungkan daripada yang berasal dari perempuan. Ada pula keyakinan terkait dengan pembagian divisi pekerjaan antara laki-laki dan perempuan yang mana aktivitas di dalam rumah seperti mengurusi keluarga, memasak, mencuci, dan sebagainya sedangkan laki-laki melakukan aktivitas yang di luar rumah seperti berpartisipasi dalam politik, dll. Hal tersebut menyebabkan berkembangnya hierarki dan pemikiran di berbagai kawasan India bahwasanya laki-laki berada pada nomor satu sedangkan wanita di nomor kedua (Kassa, 2015). 
Dampak utama yang akan terjadi apabila partisipasi politik dari wanita masih minim adalah ketidaksetaraan gender serta isu-isu diskriminasi terhadap wanita pun akan tetap kerap terjadi. Untungnya, berdasarkan dari penelitian Nisha \& Vezhaventhan (2018) menyatakan bahwasanya berdasarkan data statistik partisipasi politik wanita rata-rata mengalami kenaikan walaupun tidak secara signifikan. Itu berarti mulai ada kesadaran dari para wanita untuk menyuarakan hak-haknya serta usaha agar tidak terdiskriminasi di sektor-sektor umum.

Isu kesetaraan gender yang disuarakan oleh para feminisme ini bukan berarti antara laki-laki dan wanita menjadi sama tetapi lebih kepada memberikan kesadaran bahwasanya para wanita juga memiliki hak-hak untuk berpendapat, hak untuk memilih sesuatu, hak untuk mengenyam pendidikan, dan lain-lain. Tanpa ada kesadaran tersebut, wanita akan selalu menjadi pihak yang dirugikan tidak hanya di sektor umum seperti tempat kerja dan pemerintahan melainkan juga di sektor-sektor privat seperti rumah tangga. Adanya kesetaraan gender juga merupakan suatu bentuk sistem demokrasi untuk berjalan dengan lancar sehingga dapat menciptakan suatu tata kelola yang baik. Di dalam karakteristik utama good governance terdapat poin partisipasi yang mana partisipasi dari laki-laki dan wanita merupakan kunci utama untuk menciptakan suatu tata kelola yang baik (good governance) (UNESCAP, nd). Dalam tata kelola yang baik menyebutkan bahwa setiap pihak harus berpartisipasi aktif sehingga pemerintah dapat mengeluarkan suatu kebijakan yang dapat memenuhi kebutuhan masyarakatnya dan masyarakat pun mendapatkan hak mereka (Bundschuh-Rieseneder, 2008).

\section{Korelasi Korupsi dan Kesetaraan Gender di India dan Solusi dalam Menciptakan Good Governance}

Di dalam karakteristik good governance, isu korupsi dan kesetaraan gender tidak mewakili beberapa poin di antaranya seperti partisipasi, peraturan dalam hukum, transparansi, serta poin efektivitas dan efisiensi. Sudah jelas hal tersebut menjadi penyebab tidak terciptanya good governance di India. Antara indikator korupsi dan kesetaraan gender itu sendiri memiliki suatu korelasi. Adanya korelasi terkait dengan korupsi dan gender ini pun masih menjadi perdebatan antara para 
ahli di dunia internasional. Beberapa ahli menyatakan bahwa tidak ditemukan suatu korelasi. Namun di sisi lain, banyak pula ahli yang menemukan korelasi antara korupsi dan gender melalui penelitiannya yang bersifat empiris.

Seperti yang telah penulis sebutkan sebelumnya, penulis melihat apabila kasus korupsi suatu dimensi gender terdapat korelasi mekanisme sebab akibat. Pasalnya, beberapa sumber telah menjabarkan bahwasanya adanya korelasi antara tingkat korupsi dengan pemberdayaan perempuan yang mana semakin tinggi tingkat partisipasi wanita dalam politik khususnya partisipasi wanita dalam pembuatan kebijakan di suatu negara menunjukkan semakin rendah tingkat korupsi di negara tersebut (UKAid, 2015).

Sebaliknya, apabila tingkat partisipasi wanitanya rendah maka tingkat korupsi di negara itu cenderung tinggi. Hal tersebut disebabkan oleh:

a. Wanita melihat tindakan korupsi sebagai suatu tindakan yang sangat berisiko dan wanita lebih cenderung untuk tidak mengambil tindakan yang berisiko tinggi.

b. Wanita melihat tindakan korupsi sebagai sesuatu yang tabu untuk dilakukan sehingga akan ada tekanan sosial tersendiri bagi wanita apabila melakukan hal tersebut.

c. Wanita cenderung lebih memegang teguh nilai dan moral daripada laki-laki. Kebanyakan wanita memandang posisi dalam pemerintahan merupakan suatu prestasi yang sangat berharga, kesempatan yang sangat langka, dan beruntung karena dapat ikut andil di dalamnya sehingga mereka cenderung untuk tidak melakukan tindak korupsi yang dapat menodai prestasinya tersebut. Seperti contohnya di India sendiri, isu-isu diskriminasi yang dirasakan oleh kaum wanita, hak-hak wanita yang tidak terpenuhi, serta kebijakan publik yang cenderung menguntung kaum laki-laki daripada perempuan disebabkan karena adanya gender gap dalam pemerintahan dan birokrasi yang didominasi oleh laki-laki. Di sisi lainnya, tindak korupsi pun masif dilakukan karena hal itu sudah menjadi hal lumrah untuk dilakukan sedangkan bagi wanita itu merupakan hal yang tabu. Tindak korupsi yang dilakukan pun umumnya hanya menguntungkan pihak laki- 
laki karena kaum perempuan cenderung memutuskan untuk tidak terlibat ke dalamnya.

Untuk melanggengkan dan memudahkan tindakan-tindakan korupsi lainnya, maka kursi-kursi pemerintahan dan birokrasi terus didominasi oleh lakilaki sehingga akan terus mengakibatkan adanya gender gap di dalam perpolitikan. Oleh karena itu, India akan sulit untuk mencapai suatu tata kelola yang baik (good governance) apabila isu korupsi dan ketidaksetaraan gender masih sangat melekat di kehidupan masyarakat India sehari-hari. Untuk mengurangi tingkat korupsi dan gender gap di India untuk menciptakan suatu tata kelola yang baik adalah perlu adanya partisipasi wanita yang lebih aktif lagi tidak hanya di sektor-sektor publik melainkan partisipasi secara politik untuk dapat andil dalam pemutusan suatu kebijakan.

Dengan adanya partisipasi politik dari wanita dalam pemutusan kebijakan maka dapat menyuarakan hak-hak wanita yang selama ini terlupakan atau terabaikan karena power yang dimiliki oleh wanita cenderung dianggap lebih lemah dibandingkan laki-laki. Untuk meningkatkan partisipasi politik dari wanita itu sendiri sangat diperlukan adanya pemberdayaan perempuan atau pemberdayaan perempuan dalam skala besar. Hal tersebut berguna untuk membentuk pola pikir baru, pandangan serta nilai baru bahwasanya wanita juga bisa menjadi seperti lakilaki. Wanita juga memiliki hak-hak peran seperti laki-laki, wanita dapat menjadi sosok pemimpin dan wanita juga berhak untuk menentukan pilihannya sendiri.

Dengan adanya pola pikir yang baru, maka diharapkan generasi-generasi wanita muda di India tergerak untuk mengenyam pendidikan yang lebih layak dan lebih tinggi lagi untuk mencapai cita-citanya seperti yang diinginkan. Dengan pendidikan yang lebih tinggi maka akan membuka pemikiran-pemikiran baru yang lebih kritis sehingga meningkatkan kesempatan untuk dapat andil langsung dalam pemutusan kebijakan di pemerintahan. Adanya peningkatan partisipasi wanita secara signifikan dalam politik diharapkan dapat mengurangi kesempatan tindak korupsi.

Selain itu, perlu adanya koneksi sosial dan kerja sama yang erat antar masyarakat. Koneksi sosial berguna untuk menyebarkan pengaruh ke dalam suatu 
lingkup lingkungan. Koneksi sosial itu sendiri terbentuk dari adanya kerja sama yang erat antar masyarakat. Kerja sama untuk saling mengingatkan dan menyadarkan perilaku-perilaku yang tidak baik untuk dilakukan sehingga dapat membentuk suatu kebiasaan baru yang lebih baik. Setelah terbentuk kebiasaan baru yang lebih baik itu, dengan adanya koneksi secara sosial maka kebiasaan baru itu akan mudah mempengaruhi pihak-pihak lainnya. Masyarakat juga harus lebih pintar lagi dalam memilih wakil-wakilnya yang duduk di kursi pemerintahan serta harus lebih kritis lagi dalam melihat dan mengevaluasi tindak lanjut dari tindakantindakan korupsi yang dilakukan oleh para birokrat.

\section{KESIMPULAN}

Isu korupsi dan kesetaraan gender sudah menjadi semacam penyakit dalam yang sulit sekali disembuhkan. India sebagai negara berkembang yang cukup besar di wilayah Asia masih berurusan dengan masalah tersebut hingga saat ini. Adanya mis-manajemen, serta kesenjangan ekonomi menjadi penyebab korupsi di negara tersebut yang kemudian berdampak kepada kemiskinan, kelaparan, tingkat pengangguran dan masalah-masalah yang bersifat sosio-ekonomi lainnya. Begitu pula dengan permasalahan kesetaraan gender yang salah satu penyebabnya adalah budaya serta nilai yang dianut oleh masyarakat India itu sendiri yang menempatkan laki-laki di atas wanita dan menganggap wanita hanya dapat melakukan pekerjaanpekerjaan yang bersifat privat atau di dalam rumah tangga. Kedua indikator tersebut pula menjadi penyebab utama tidak terciptanya tata kelola yang baik di India karena kurangnya transparansi, hukum yang mudah disuap, birokrasi dan kebijakan yang tidak efektif dan efisien serta adanya gender gap dalam partisipasi masyarakat khususnya dalam perpolitikan yang masih didominasi oleh laki-laki.

Oleh karena itu, untuk menciptakan suatu tata kelola global diperlukan adanya pemberdayaan perempuan dalam skala besar yang bertujuan untuk mengubah pola pikir wanita di India serta adanya koneksi sosial dan kerja sama yang erat antar masyarakat untuk sama-sama menjadi pengawas dan melakukan evaluasi terhadap perihal yang menyimpang dari sebagaimana mestinya. Korupsi dan kesetaraan gender memang mustahil dapat hilang dari muka bumi ini namun 
alangkah baiknya apabila rasionya semakin berkurang dan terciptanya suatu tata kelola yang baik sehingga permasalahan dalam negara itu pun dapat berkurang karena pemerintahannya sudah tertata dengan baik.

\section{DAFTAR PUSTAKA}

Bundschuh-Rieseneder, Friederike. (2008). Good Governance: Characteristics, Methods, and The Austrian Examples. Transylvanian Review of Administrative Sciences. Pp 26-52.

Bhayam, Madhvi. (2014). Challenges of Corruption and Good Governance: A Human Rights Perspective. DOI: 10.7763/IPEDR. 2014. V71. 6

Department for International Development UK Aid. (2015). Why Corruption Matters: $\quad$ Understanding Causes, Effects, and How to Adress Them. UK Aid. Dilansir dari https://assets.publishing.service.gov.uk/government/uploads/system/uploa ds/attachme nt_data/file/406346/corruption-evidence-paper-whycorruption matters.pdf pada $15 \quad$ April, 20.00 WIB.

Ganguly, Sumit. (2012). Corruption in India: An Enduring Threat. Journal of Democracy. Vol 23(1). Pp 138-148.

Jha, Priti. (2015). A Study of Gender Inequality in India. The International Journal of Indian Psychology Volume 2, issue 3. DOI: B00344V2I32015

Kassa, Shimelis. (2015). Challenges and Opportunities of Women Political Participation in Ethiopia. Journal of Global Economics. Vol 03.

Krishnaveni D. (2017). Gender Equity and Political Participation. IOSR Journal of Humanities and Social Science. Vol 22(10). Pp 01-04.

Kohli, Sugandha (2017). Gender Inequality in India. International Journal of Humanities and Social Science Studies. Vol-III, Issue-IV, Pp. 178-185

Kundu, Mousumi. (2015). Some Aspects of Corruption in India in 21st Century. International Journal of Scientific and Research Publications. Vol 5 (12). Pp 155-205.

Miklian, Jason \& Carney, Scott. (2013). Corruption, Justice, and Violence in Democratic India. SAIS Review. Vol 33(1). Pp 37-49.

Ministry of Statistics and Programme Implementation Government of India. (2018). Women and Men in India: A Statistical Compilation of Gender Related Indicators in India. Government of India. Dilansir dari 
http://www.mospi.gov.in/sites/default/files/publication_reports/Women\%2 0and\%20 Men\%20\%20in\%20India\%202018.pdf pada 23 April 2020, 13.20 WIB.

Minocha, O.P. (1998). Good Governance: New Public Management Perspective. Indian Journal of Public Administration, Vol. 44, No.3, Pp. 270-280

Nisha, M Ameen \& Vezhaventhan, D. (2018). Political Empowerment and Participation of Women in India. International Journal of Pure and Applied Mathematics. Vol 120(5). Pp 4721-4736.

Rajak, Jeevan S. (2013). Corruption in India: Nature, Causes, Consequences, and Cure. IOSR Journal of Humanities and Social Science. Vol 18 (5). Pp 2024.

Saxena, Abhay. Corruption in India - Causes and Solution. Anamika Publishers and Distributers Pvt.Ltd. DOI: 10.13140/RG.2.1.1386.5446

Sumanjeet, Singh. (2016). The State of Gender Inequality in India. Gender Studies. Pp 139-

157. DOI: $10.1515 /$ genst-2017-0009

Transparency International. (2019). Corruption Perception Index 2019. Transparency International. Dilansir dari https://www.transparency.org/cpi2019 pada 17 April 2020, 14.00 WIB.

United Nations Childern's Fund. (2017). Glosary of Terms and Concepts. UNICEF. Dilansir dari https://www.unicef.org/rosa/media/1761/file/Gender\%20glossary\%20of\% 20terms\%2 0and\%20concepts\%20.pdf pada 19 April 2020, 13.45 WIB.

United Nations Development Programme. (2018). Human Development Reports: Gender Inequality Index (GII). UNDP. Dilansir dari http://hdr.undp.org/en/content/table-5- gender-inequality-index-gii pada 20 April 2020, 19.15 WIB.

United Nations Economic and Social Commision for Asia and the Pasific. (n.d). What is Good Governance. UNESCAP. Dilansir dari https://www.unescap.org/sites/default/files/good-governance.pdf pada tanggal 14 April 2020, 18.00 WIB. 